\title{
Analisis Pengaruh Faktor Meteorologi dan Unsur Ruang Terhadap Nilai Reduksi Sulfur Dioksida Udara Ambien di Kota Surabaya
}

\author{
Mohammad Ma'ruf Al Anshari dan R. Irwan Bagyo Santoso \\ Departemen Teknik Lingkungan, Fakultas Teknik Sipil dan Perencanaan, Institut Teknologi Sepuluh \\ Nopember (ITS) \\ e-mail: irwan080565@gmail.com
}

\begin{abstract}
Abstrak-Polusi udara merupakan dampak nyata atas perkembangan yang terjadi pada sektor transportasi dan industri utamanya di perkotaan. Salah satu parameter pencemaran udara yaitu gas sulfur dioksida, dimana gas ini berbahaya bagi manusia dan lingkungan karena dapat menyebabkan penyakit pernafasan juga merusak struktur daun dan dapat memicu terjadinya hujan asam. Salah satu upaya untuk mengurangi nilai konsentrasi sulfur dioksida di perkotaan, yaitu dengan menggunakan tanaman perkotaan atau Ruang Terbuka Hijau (RTH). Tujuan penelitian ini adalah untuk menentukan pengaruh dari faktor meteorologi serta faktor unsur ruang, utamanya faktor RTH terhadap nilai reduksi $\mathrm{SO}_{2}$ yang terjadi selama 24 jam. Penelitian ini dilakukan di daerah sekitar SPKU Wonorejo, Surabaya, dimana lokasi tersebut dapat mewakili wilayah permukiman dan ruang terbuka hijau menurut peta kotamadya Kota Surabaya. Analisis data membutuhkan data spasial berupa citra satelit dari wilayah penelitian yang akan digunakan untuk membangun model box, serta data non spasial berupa data meteorologi selama waktu tertentu yang tercatat di SPKU Wonorejo. Hasil penelitian terlihat bahwa (1) ada pengaruh negatif antara faktor meteorologi dengan nilai konsentrasi $\mathrm{SO}_{2}$, dan (2) faktor yang paling berpengaruh signifikan terhadap nilai reduksi $\mathrm{SO}_{2}$ adalah kelembaban udara dengan taraf nyata atau $\boldsymbol{P}$-value dibawah 0,05. Selain itu, (3) hasil korelasi juga menghasilkan persamaan berupa $Y=3,12 v+3,82 \mathrm{~T}+\mathbf{0 , 1 7 H}+1737,38 \mathrm{r}+1758,77 \mathrm{j}+$ $1731,64 b+1783,48 r-1628,53$, dimana persamaan tersebut dapat digunakan untuk menurunkan nilai $\mathrm{K}_{\mathrm{SO} 2}$ serta memberikan hasil akurat $\left(R^{2}>0,6\right)$ dengan syarat diimplikasikan pada faktor-faktor meteorologi dan unsur ruang yang berada pada range tertentu.
\end{abstract}

Kata Kunci - model box, polusi udara, ruang terbuka hijau, sulfur dioksida

\section{PENDAHULUAN}

$\mathrm{P}$ OLUSI udara merupakan salah satu dampak negatif dari perkembangan pada sektor transportasi dan industri di zaman milenium ini, polusi udara sendiri bermakna adanya zat-zat asing di dalam udara yang menyebabkan perubahan susunan atau komposisi udara dari keadaan normalnya [1]. Salah satu satu parameter pencemar udara yang berasal dari gas buangan kendaraan bermotor, adalah gas sulfur dioksida $\left(\mathrm{SO}_{2}\right)$. Gas sulfur dioksida adalah salah satu gas yang berasal dari sisa pembakaran mesin diesel utamanya kendaraan bermotor, dimana dalam proses pembakaran bahan bakar fosil akan turut pula menghasilkan berbagai macam bahan kimia temasuk belerang (sulfur) dalam jumlah kecil, belerang tersebut akan bereaksi dengan oksigen dan membentuk sulfur dioksida [2]. Efek dari gas $\mathrm{SO}_{2}$, salah satunya yaitu pada kadar 5 ppm akan dapat menyebabkan iritasi mata serta gangguan pernafasan. Hal tersebut karena gas $\mathrm{SO}_{2}$ dapat berubah menjadi asam yang dapat menyerang langsung selaput lendir yang ada pada hidung, tenggorokan dan saluran pernafasan lainnya [3].

Karena itu, baku mutu yang dipatok untuk konsentrasi sulfur dioksida tidak boleh melebihi angka $500 \mu \mathrm{g} / \mathrm{m}^{3}(0,175$ ppm) untuk jangka pendek 10 menit, sedangkan untuk jangka panjang 24 jam dipatok baku mutu sulfur dioksida sebesar 125 $\mu \mathrm{g} / \mathrm{m}^{3}$ (0,04 ppm) [4]. Di Indonesia sendiri, konsentrasi $\mathrm{SO}_{2}$ di lima kota besar termasuk Kota Surabaya masih berada pada angka aman atau di bawah batas baku mutu konsentrasi $\mathrm{SO}_{2}$ yang ditentukan, yaitu berada pada angka 0,0248 ppm [5]. Namun, meskipun demikian, mengingat akan bahaya dari gas sulfur dioksida, diperlukan adanya langkah untuk mereduksi angka konsentrasi sulfur dioksida tersebut hingga mencapai angka yang lebih rendah lagi. Salah satu caranya adalah menggunakan tanaman yang ada di perkotaan sebagai penyerap polutan, tanaman di perkotaan atau ruang terbuka hijau (RTH) memiliki fungsi sebagai pemberi estetika, penyeimbang iklim, penekan dampak pencemaran udara serta sebagai sumber penghasil oksigen [6].

Besarnya tingkat reduksi sulfur diksida dapat dilihat dari nilai reduksi $\mathrm{SO}_{2}$ yang terjadi. Nilai reduksi pencemar $\mathrm{SO}_{2}$ dapat ditentukan dari nilai kumulatif konsentrasi udara ambien selama 24 jam ( $\left.\mathrm{K}_{\mathrm{SO} 2}\right)$. Apabila $\mathrm{K}_{\mathrm{SO} 2} 24$ jam diketahui bertanda negatif (-), maka menunjukkan reduksi $\mathrm{SO}_{2}$ lebih besar dari sumber emisi. Sebaliknya, jika nilai kumulatif konsentrasi $\mathrm{SO}_{2}$ diketahui bertanda positif (+) menunjukkan reduksi $\mathrm{SO}_{2}$ lebih kecil dari sumber emisi [7]. Permasalahan yang terjadi yaitu belum adanya studi terkait yang mengkaji tentang faktor apa saja yang mempengaruhi nilai konsentrasi tersebut, oleh karena itu perlu dilakukan studi untuk memperoleh informasi apa saja faktor yang paling berpengaruh secara signifikan untuk mengurangi konsentrasi sulfur dioksida udara ambien.

Berdasarkan latar belakang tersebut, maka tujuan penelitian ini adalah untuk memperoleh dan menentukan bagaimana pola konsentrasi serta pola laju kumulatif $\mathrm{SO}_{2}$ yang terjadi pada sekitar kawasan stasiun pemantau kualitas udara Wonorejo, dimana lokasi SPKU Wonorejo dapat mewakili kawasan permukiman dan ruang terbuka hijau (RTH). Serta 
menentukan pengaruh dari faktor-faktor apa saja yang dianggap berpengaruh secara signifikan terhadap konsentrasi sulfur dioksida dan $\mathrm{K}_{\mathrm{SO} 2}$ udara ambien. Metode dalam penelitian ini menggunakan metode Model box atau penyerupaan bentuk kubus, dimana Model box digunakan untuk mengetahui seberapa besar tingkat reduksi dan emisi yang terjadi di titik penelitian tiap rentang 30 menit selama 24 jam $\left(\mathrm{K}_{\mathrm{SO} 2}\right)$.

\section{METODE PENELITIAN}

\section{A. Bahan}

Lokasi pengamatan dilakukan pada wilayah sekitar Stasiun Pemantau Kualitas Udara Wonorejo yang terletak di dalam Taman Bibit 2 Wonorejo, tepatnya di jalan Kendalsari, Kecamatan Rungkut. Apabila dilihat pada posisi geografisnya, terletak pada $7^{\circ} 18^{\prime} 42.71^{\prime \prime}$ LS dan $112^{\circ} 47^{\prime} 20.95^{\prime \prime}$ BT. Lokasi RTH dan SPKU Wonorejo ditampilkan pada Gambar 1 dan 2 berikut.

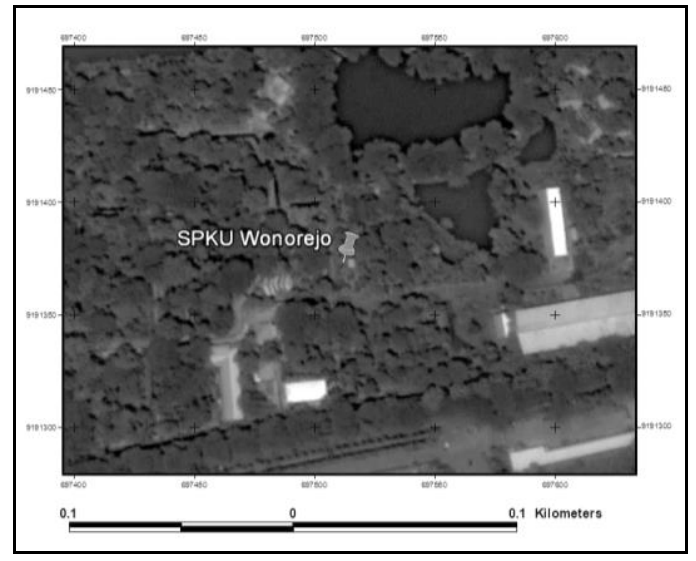

Gambar 1. Lokasi SPKU Wonorejo.

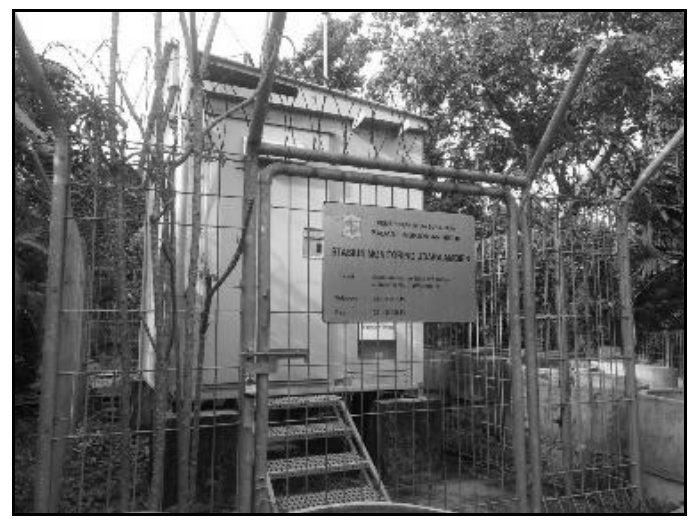

Gambar 2. Stasiun Pemantau Kualitas Udara Wonorejo.

Data yang digunakan meliputi data spasial yaitu data citra satelit Google Earth yang merekam keadaan lahan di sekitar SPKU Wonorejo dari tahun 2013 hingga 2016, serta data non spasial yaitu data meteorologi meliputi data kecepatan angina, suhu, kelembaban udara dan konsentrasi sulfur dioksida yang terekam oleh Stasiun Pemantau Wonorejo. Data non spasial tersebut akan dicocokkan dengan data spasial, dimana 1 data citra akan membutuhkan 7 data meteorologi sebagai pembanding keadaan lahan dalam waktu seminggu. Sehingga jumlah citra yang digunakan sebanyak 10 buah citra, meliputi citra tanggal 6 Maret 2013, 30 April 2013, 17 September 2013, 14 Oktober 2013, 7 Agustus 2014, 20 April 2015, 19 Juli 2016, 12 Agustus 2016, 8 September 2016, dan 18 Nopember 2016.

\section{B. Metode}

Data non spasial yang berupa data konsentrasi sulfur dioksida digunakan untuk mengetahui bentuk pola konsentrasi sulfur dioksida harian yang terjadi selama 24 jam, selain itu data konsentrasi $\mathrm{SO}_{2}$ tersebut digunakan untuk menentukan laju nilai kumulatif konsentrasi sulfur dioksida yang terjadi $\left(\mathrm{K}_{\mathrm{SO} 2}\right)$, dimana $\mathrm{K}_{\mathrm{SO} 2}$ adalah beda nilai konsentrasi $(\Delta \mathrm{C})$ untuk selang waktu $(\Delta \mathrm{t})$. Laju perubahan nilai konsentrasi sulfur dioksida merupakan integral dari fungsi konsentrasi $\mathrm{SO}_{2}$ dibagi dengan fungsi waktu dalam satu periode, atau dapat dinyatakan dengan rumus berikut:

$\mathrm{K}_{\mathrm{SO} 2}=\int \frac{\Delta \mathrm{C}}{\Delta \mathrm{t}} \cdot \mathrm{dt}$

Hasil dari perhitungan $\mathrm{K}_{\mathrm{SO} 2}$ dapat menjadi indikator tejadinya pengurangan konsentrasi $\mathrm{SO}_{2}$ udara ambien, dimana apabila $\mathrm{K}_{\mathrm{SO} 2}$ bernilai positif artinya selama satu periode maka bermakna terjadi penambahan (emisi) $\mathrm{SO}_{2}$ di udara ambien, sebaliknya bila bernilai negatif terjadi pengurangan (reduksi) $\mathrm{SO}_{2}$ dari udara ambien.

Penelitian ini digunakan unit analisis berupa model box, dimana unit analisis tersebut didapat dari bergantung pada arah angina dan kecepatan angin harian yang terekam pada SPKU wonorejo, sehingga dimensi unit analisis tersebut bervariasi pada setiap tanggal pengamatan [8]. Panjang sisi model box didapatkan dari hasil kali kecepatan angin rata-rata selam 24 jam dengan waktu hidup alat rekam konsentrasi sulfur dioksida yaitu selama 1 menit (60 detik), sedangkan arah box mengikuti arah angin rata-rata selama 24 jam yang terekam pada SPKU Wonorejo. Ilustrasi unit analisis (model box) ditampilkan pada Gambar 3 berikut,

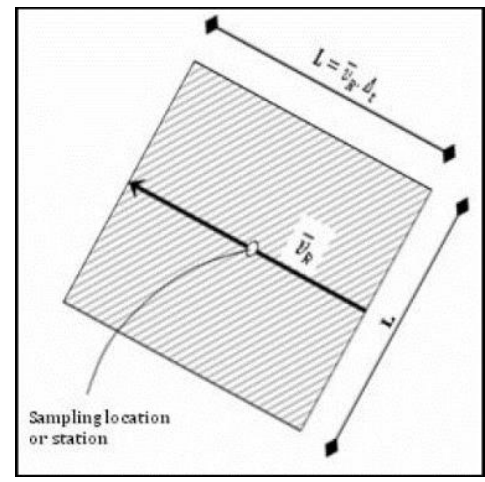

Gambar 3. Unit Analisis dalam Penelitian.

Unit analisis tersebut selanjutnya diobservasi dengan melakukan rektifikasi serta delineasi lahan pada model box menggunakan program Global Mapper 8 dan Arc View 3.3. Hasil delineasi lahan serta data meteorologi akan dikorelasikan dengan nilai $\mathrm{K}_{\mathrm{SO} 2}$ untuk dilihat pengaruhnya terhadap nilai reduksi sulfur dioksida. 


\section{HASIL DAN PEMBAHASAN}

Analisis data yang dilakukan meliputi pengamatan pola konsentrasi $\mathrm{SO}_{2}$ harian dan laju kumulatif $\mathrm{SO}_{2}$ yang terjadi, pengamatan unit analisi (model box) serta uji korelasi dan regresi untuk melihat pengaruh faktor meteorologi dan juga faktor unsur ruang, utamanya faktor RTH terhadap reduksi sulfur dioksida yang terjadi selama 24 jam.

\section{A. Pola Konsentrasi Sulfur Dioksida 24 jam}

Data konsentrasi sulfur dioksida udara ambien yang telah terkumpul, dianalisis bagaimana pola konsentrasi harian yang terbentuk. Setiap tanggal pengamatan memiliki pola yang tidak sama atau bervariatif, hal tersebut dapat disebabkan karena adanya perbedaan pada jumlah emisi yang ada dan juga faktor meteorologi yang meliputi kecepatan angin, suhu atau juga kelembapan udara. Namun, umumnya setiap pola konsentrasi memiliki satu ciri identik yang dapat ditemui pada hampir setiap pola konsentrasi, dimana terdapat pola meningkat dan mengarah pada fase puncak pada saat pagi hari antara pukul setengah 6 pagi hingga pukul 9 pagi, dimana pada jam-jam tersebut volume kendaraan yang melintas di sekitar wilayah penelitian masih padat dikarenakan pada pagi hari tersebut aktivitas pergi ke kantor, ke sekolah dan aktivitas lainnya masih cenderung tinggi dibandingkan pada jam lainnya [9], sehingga emisi sulfur dioksida yang terekam oleh SPKU Wonorejo cenderung tinggi pada pagi hari.

Dalam pengamatan pola konsentrasi ini, setiap tanggal citra diwakilkan dengan 7 (tujuh) tanggal pengamatan. Ketujuh tanggal pengamatan tersebut dianggap mewakili kondisi meteorologi yang representatif dengan tanggal citra yang ada, dimana pola tersebut mewakili 3 hari sebelum citra diambil, hari citra diambil dan 3 hari setelah citra diambil. Berikut contoh pola konsentrasi $\mathrm{SO}_{2}$ pada tanggal citra 7 Agustus 2014 ditunjukkan pada Gambar 4 berikut.

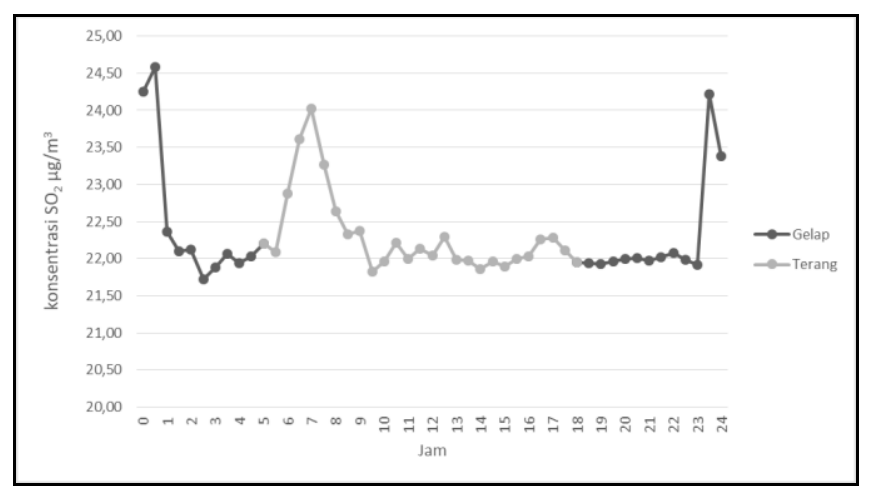

Gambar 4. Pola Konsentrasi $\mathrm{SO}_{2}$ Tanggal 7 Agustus 2014.

Pada pola konsentrasi tersebut cenderung memiliki pola dimana konsentrasi $\mathrm{SO}_{2}$ masih sedikit meningkat, namun tidak signifikan selepas jam-jam sibuk atau jam kantor. Kondisi pola konsentrasi tersebut dapat terjadi karena adanya peningkatan jumlah emisi kendaraan bermotor atau sumber lainnya seperti adanya pembakaran sampah di TPS yang berada di samping Taman Bibit 2 atau juga dapat disebabkan oleh kondisi suhu dan kelembaban yang terekam berada pada nilai yang lebih rendah daripada tanggal lainnya.

\section{B. Pola Laju Kumulatif $\mathrm{SO}_{2}\left(\mathrm{~K}_{\mathrm{SO} 2}\right) 24 \mathrm{Jam}$}

Nilai laju kumulatif konsentrasi $\mathrm{SO}_{2}$ didapatkan dari hasil integral kurva konsentrasi $\mathrm{SO}_{2}$ dibagi dengan fungsi waktu $(\Delta \mathrm{C} / \Delta \mathrm{t})$. Hasil perhitungan tersebut nantinya dapat digunakan sebagai indikator proses reduksi $\mathrm{SO}_{2}$ yang terjadi. Jika nilai $\mathrm{K}_{\mathrm{SO} 2}$ bertanda negatif (-) artinya reduksi $\mathrm{SO}_{2}$ lebih besar dari emisi $\mathrm{SO}_{2}$, sebaliknya apabila nilai $\mathrm{K}_{\mathrm{SO} 2}$ bertanda positif (+) berarti reduksi $\mathrm{SO}_{2}$ lebih kecil dari emisi $\mathrm{SO}_{2}$. Apabila nilai $\mathrm{K}_{\mathrm{SO} 2}$ sama dengan nol artinya proses reduksi maupun emisi $\mathrm{SO}_{2}$ udara ambien berjalan seimbang.

Hasil perhitungan nilai kumulatif konsentrasi sulfur dioksida tersebut selanjutnya diplotkan pada grafik untuk melihat pada periode waktu berapa saja tingkat konsentrasi kumulatif $\mathrm{SO}_{2}$ mengalami peristiwa reduksi dan emisi. Pada grafik akan terlihat perbedaan luasan kurva yang membentuk lembah dan gunung. Kurva dibawah nol atau berbentuk lembah dapat diartikan bahwa proses reduksi emisi sulfur dioksida terjadi saat itu, sedangkan kurva diatas nol atau berbentuk gunung berarti pada periode tersebut terjadi proses emisi sulfur dioksida Berikut ini contoh analisis pola laju kumulatif $\mathrm{SO}_{2}$ pada tanggal citra 7 Agustus 2014 ditampilkan pada Gambar 5.

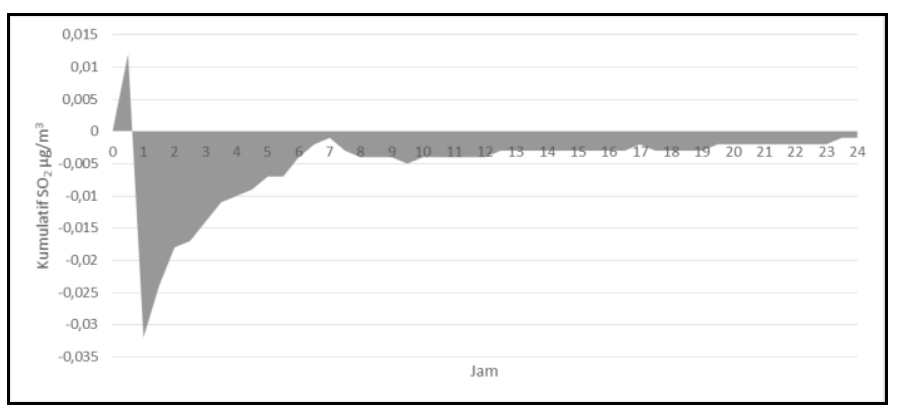

Gambar 5. Laju K SO2 $_{\text {Pada Tanggal }} 7$ Agustus 2014.

Pada pola laju $\mathrm{K}_{\mathrm{SO} 2}$ tersebut, grafik terlihat memliki bentuk lembah yang berarti nilai perhitungan $\mathrm{K}_{\mathrm{SO} 2}$ bertanda negatif atau bernilai minus sehingga dapat dikatakan bahwa pada tanggal 7 Agustus 2014, RTH pada daerah penelitian berhasil melakukan proses reduksi sulfur dioksida lebih banyak daripada emisi sulfur dioksida yang ada. Dengan kata lain, RTH pada tanggal 7 Agustus 2014 tersebut sudah mencukupi dan efektif dalam mereduksi konsentrasi sulfur dioksida yang ada di udara. Namun, dalam analisis seluruh pola $\mathrm{K}_{\mathrm{SO} 2}$ pada tiap tanggal pengamatan, didapat pola $\mathrm{K}_{\mathrm{SO} 2}$ cenderung berbntuk gunung atau nilai $\mathrm{K}_{\mathrm{SO} 2}$ positif sebanyak 52 pola dari 70 pola pengamatan. Hal tersebut bermakna bahwa RTH pada kawasan penelitian belum terlalu mampu untuk mereduksi konsentrasi sulfur diokasida yang ada.

\section{Pembuatan dan Pengamatan Unit Analisis}

Unit analisis dalam penelitian ini yang berupa Model box dibuat berdasarkan data kecepatan serta arah angin. Ukuran dan luas box akan berubah sesuai data kecepatan serta arah angin yang terjadi pada saat hari pengamatan. Luas box didapatkan dari hasil kali data kecepatan angin rata-rata selama 24 jam dikalikan waktu sampling atau pengukuran konsentrasi $\mathrm{SO}_{2}$. Sedangkan arah atau kemiringan box, didapatkan dari hasil kali kecepatan angin dengan kuadran arah angin yang ada. Hasil dari perkalian tersebut nantinya 
akan memunculkan 2 titik koordinat sebagai titik acuan arah masuknya angin ke dalam model box. Pada contoh perhitungan unit analisis untuk tanggal citra 7 Agustus 2014, didapatkan dimensi panjang sisi model box sebesar $96 \mathrm{~m}$, dan kemiringan $139,96^{\circ}$, nilai besaran dimensi serta arah box tersebut akan dijadikan acuan untuk membuat unit analisi model box dengan program Autocad 2013 untuk selanjutnya diplotkan ke dalam citra Google Earth, sehingga nantinya dapat dianalisis unsur lahan apa saja yang ada di dalam model box tersebut.

Proses analisis model box menggunakan 2 program GIS yaitu Global Mapper 8 dan Arc View 3.3, kedua program tersebut akan digunakan untuk tahap rektifikasi dan delineasi lahan pada model box, delineasi sendiri dapat diartikan sebagai suatu proses penggambaran ruang untuk membatasi zona wilayah atau kawasan tertentu sehingga tampak perbedaan dengan zona wilayah atau kawasan di sekitarnya [10]. Unsur ruang yang diklasifikasikan dalam penelitian ini meliputi ruang terbuka hijau (RTH), jalan dan/atau lahan kosong, bangunan serta badan air. Berikut ini contoh hasil delineasi unsur RTH pada lahan model box citra tanggal 7 Agustus 2014 ditampilkan pada Gambar 6 dibawah ini.

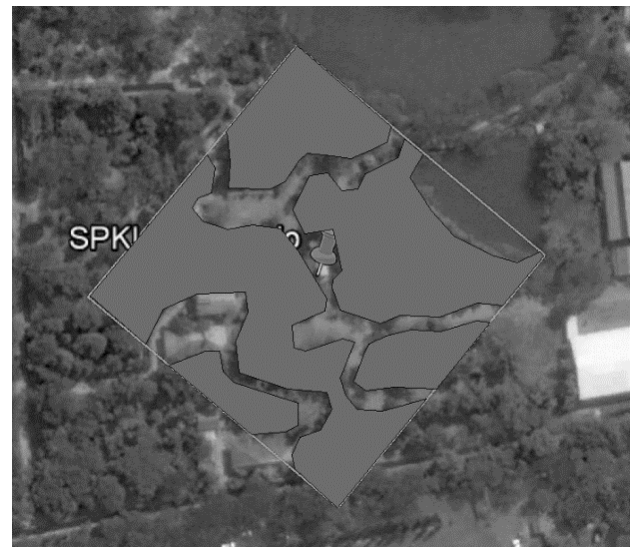

Gambar 6. Hasil Delineasi Unsur RTH pada Model Box.

Berdasarkan delineasi lahan pada model box tersebut, didapatkan persentase lahan RTH yang ada sebesar $71 \%$, proses delineasi tersebut dilakukan pula untuk unsur lahan lainnya yaitu unsur jalan dan/atau lahan kosong, bangunan dan badan air, sehingga didapatkan total presentase masing-masing unsur lahan pada model box citra 7 Agustus 2014 yaitu, 71\% RTH, $18 \%$ jalan/lahan kosong, $6 \%$ bangunan dan $5 \%$ badan air.

\section{Analisis Korelasi dan Regresi}

Setelah seluruh data persentase lahan selesai diproses, selanjutnya dilakukan uji korelasi dan regresi untuk mengetahui bagaimana pengaruh unsur ruang terutama persentase RTH terhadap laju kumulatif $\mathrm{SO}_{2}$. Selain itu, digunakan pula data faktor meteorologi seperti kecepatan angin, temperatur serta kelembaban udara. Nantinya akan dibandingkan faktor apakah yang lebih berpengaruh diantara faktor meteorologi atau faktor unsur ruang tersebut.

Hasil uji korelasi antara faktor meteorologi yang terdiri dari kecepatan angin, suhu serta kelembaban udara terhadap konsentrasi $\mathrm{SO}_{2}$, terlihat bahwa seluruh faktor meteorologi memiliki korelasi negatif atau berbanding terbalik dengan nilai konsentrasi $\mathrm{SO}_{2}$, dimana contohnya apabila semakin tinggi kecepatan angin, maka konsentrasi $\mathrm{SO}_{2}$ akan semakin rendah. Berikut ini hasil korelasi antara faktor meteorologi terhadap konsentrasi $\mathrm{SO}_{2}$ ditampilkan pada Tabel 1.

$$
\text { Tabel } 1
$$

Hasil Analisis Korelasi Faktor Meteorologi terhadap Konsentrasi $\mathrm{SO}_{2}$

\begin{tabular}{cr}
\hline & Konsentrasi \\
\hline Konsentrasi & 1 \\
\hline Kec. Angin & $-0,164755395$ \\
\hline Suhu & $-0,169106336$ \\
\hline Kelembaban & $-0,210091683$ \\
\hline
\end{tabular}

Berdasarkan Tabel 1 diketahui bahwa seluruh faktor meterologi memiliki korelasi negatif atau berbanding terbalik dengan konsentrasi $\mathrm{SO}_{2}$, hal tersebut dikarenakan polutan akan menyebar ke segala arah saat angin berhembis semakin cepat, sehingga polutan tidak terpusat pada satu titik [11], selain itu pada saat udara masuk ke dalam suatu kawasan industri yang penuh dengan polutan, maka akan menyebabkan pergerakan mendadak lapisan udara dingin, sehingga akan menimbulkan temperatur inversi, yaitu konsentrasi polutan akan semakin turun saat udara meningkat [12]. Konsentrasi $\mathrm{SO}_{2}$ juga akan semakin turun apabila kelembaban udara meingkat, hal tersebut dikarenakan saat udara lembab, polutan di udara cenderung terperangkap pada droplet-droplet air, sehingga polutan di udara mengalami penurunan [13].

Pada hasil uji regresi, menunjukkan bahwa seluruh faktor meteorologi memiliki pengaruh yang signifikan terhadap konsentrasi $\mathrm{SO}_{2}$, hal tersebut dibuktikan dari nilai taraf nyata atau $P$-value dari seluruh faktor meteorologi berada dibawah $5 \%$, berikut hasil uji regresi faktor meteorologi terhadap konsentrasi $\mathrm{SO}_{2}$ ditampilkan pada Tabel 2.

Tabel 2.

Hasil Analisis Regresi Faktor Meteorologi terhadap Konsentrasi $\mathrm{SO}_{2}$

\begin{tabular}{ccl}
\hline $\begin{array}{c}\text { Konsentrasi } \\
\mathbf{S O}_{2} \text { dengan }\end{array}$ & $\boldsymbol{P}$-Value & Keterangan \\
\hline Kec. Angin & 0,000201318 & Signifikan \\
\hline Suhu & $-2,23845 \mathrm{E}-13$ & Signifikan \\
\hline Kelembaban & $8,403 \mathrm{E}-42$ & Signifikan \\
\hline
\end{tabular}

Berdasarkan Tabel 1, diketahui bahwa seluruh faktor meteorologi terhadap konsentrasi sulfur dioksida memiliki taraf nyata atau $p$-value $<0,05$, hal tersebut dapat dinyatakan bahwa faktor meteorologi sebagai variabel yang secara parsial berpengaruh signifikan terhadap konsentrasi $\mathrm{SO}_{2}$.

Sedangkan untuk analisis korelasi antara faktor unsur ruang yang terdiri dari unsur RTH, jalan dan/atau lahan kosong, bangunan dan badan air terhadap nilai reduksi sulfur dioksida atau $\mathrm{K}_{\mathrm{SO} 2}$ menunjukkan bahwa seluruh faktor unsur ruang kecuali unsur jalan dan/atau lahan kosong berkorelasi negatif atau berbanding terbalik dengan $\mathrm{K}_{\mathrm{SO}}$, berikut ini hasil korelasi antara faktor unsur ruang terhadap $\mathrm{K}_{\mathrm{SO} 2}$ ditunjukkan pada Tabel 3 berikut ini.

Tabel 3

Hasil Analisis Korelasi Faktor Unsur Ruang terhadap $\mathrm{K}_{\mathrm{SO} 2}$

\begin{tabular}{lr} 
& Konsentrasi \\
\hline $\mathrm{K}_{\mathrm{SO} 2}$ & 1 \\
\hline$\% \mathrm{RTH}$ & $-0,047020202$ \\
\hline
\end{tabular}




\begin{tabular}{lr}
\hline$\%$ JALAN/LAHAN KOSONG & 0,10879124 \\
\hline \% BANGUNAN & $-0,045920801$ \\
\hline
\end{tabular}

Rujukan [14] menyatakan bahwa hasil korelasi antara luasan ruang terbuka hijau dengan kadar polutan yang diteliti memiliki nilai negatif, hal tersebut bermakna bahwa hubungan korelasi antara luasan RTH dengan kadar polutan berkebalikan, dimana apabila terjadi peningkatan jumlah vegetasi, maka akan diikuti dengan penurunan tingkat konsentrasi polutan. Selain itu, dilakukan uji regresi kembali untuk melihat pengaruh dari seluruh faktor baik itu faktor meteorologi ataupun faktor unsur ruang terhadap $\mathrm{K}_{\mathrm{SO} 2 \text {, dimana }}$ hasil uji regresi tersebut nantinya menghasilkan sebuah persaman linear berganda yang dapat digunakan untuk meningkatkan reduksi $\mathrm{SO}_{2}$ dalam waktu 24 jam atau untuk menurunkan nilai $\mathrm{K}_{\mathrm{SO} 2}$.

Dari 70 data faktor meteorologi dan unsur ruang yang tersedia, uji regresi ini hanya menggunakan 49 data gabungan dari faktor meteorologi serta faktor unsur ruang, 49 jumlah data ini berfungsi sebagai data training atau data percobaan untuk membuat persamaan regresi (data in sample). Sedangkan 21 data gabungan lainnya digunakan sebagai data testing atau data uji kalibrasi persamaan yang telah dibuat (data out sample). Berikut ini hasil uji regresi seluruh faktor terhadap $\mathrm{K}_{\mathrm{SO} 2}$ ditunjukkan pada Tabel 4.

Tabel 4

Hasil Analisis Regresi Seluruh Faktor terhadap $\mathrm{K}_{\mathrm{SO} 2}$

\begin{tabular}{ccc}
\hline K$_{\text {SO2 }}$ dengan & $\boldsymbol{P}$-Value & Keterangan \\
\hline Kecepatan Angin & 0,0641 & Tidak Signifikan \\
\hline Suhu & 0,270 & Tidak Signifikan \\
\hline Kelembaban & 0,014 & Signifikan \\
\hline RTH & 0,050 & Signifikan \\
\hline Jalan/Lahan Kosong & 0,046 & Signifikan \\
\hline Bangunan & 0,048 & Signifikan \\
\hline Badan Air & 0,052 & Tidak Signifikan
\end{tabular}

Berdasarkan Tabel 4, terdapat empat faktor yang terlihat berpengaruh signifikan terhadap $\mathrm{K}_{\text {SO2 }}$, dengan pengaruh paling signifikan terhadap $\mathrm{K}_{\mathrm{SO} 2}$ terlihat pada faktor kelembaban udara, dimana faktor kelembaban memiliki $P$-value sebesar 0,014. Hasil regresi tersebut juga menghasilkan sebuah persamaan linear berganda yaitu sebagai berikut:

$\mathrm{Y}=3,12 v+3,82 T+0,17 H+1737,38 r+1758,77 j+1731,64 b$

$$
+1783,48 b a-1628,5
$$

Dimana:

$\mathrm{Y}=$ nilai reduksi $\mathrm{SO}_{2}\left(\mathrm{KsO}_{2}\right) \quad \mathrm{r}=\%$ luas $\mathrm{RTH}(\%)$

$\mathrm{v}=$ kecepatan angin $(\mathrm{m} / \mathrm{s}) \quad \mathrm{j}=\%$ luas jalan/lahan kosong $(\%)$

$\mathrm{T}=$ suhu udara $\left({ }^{\circ} \mathrm{C}\right) \quad \mathrm{b}=\%$ luas bangunan $(\%)$

$\mathrm{H}=$ kelembaban udara $(\%) \quad \mathrm{ba}=\%$ luas badan air $(\%)$

Rujukan [15] menyatakan bahwa sebuah persamaan harus memiliki hasil korelasi $\mathrm{R}^{2}>0,6$ supaya persamaan tersebut dapat dinyatakan sebagai persamaan yang akurat. Berikut hasil kalibrasi persamaan untuk membuktikan validitas persamaan ditampilkan pada Gambar 7 berikut

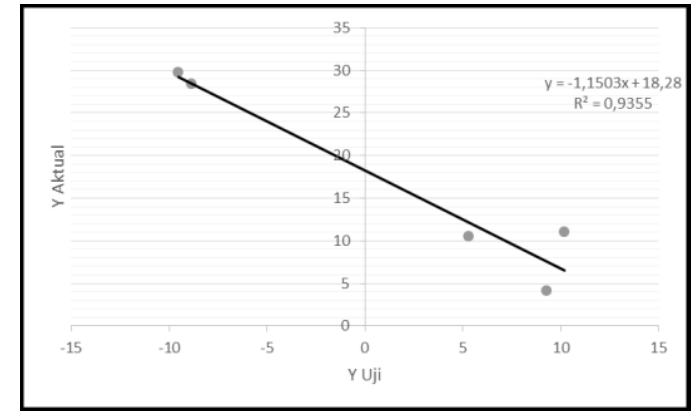

Gambar 7. Hasil Uji Korelasi $\mathrm{R}^{2}$ Persamaan

Setelah melalui proses kalibrasi persamaan, persamaan tersebut dapat digunakan untuk meningkatkan nilai reduksi $\mathrm{SO}_{2}$ serta memberikan hasil akurat $\left(\mathrm{R}^{2}>0,6\right)$ apabila diimplikasikan pada kondisi sebagai berikut:

a. Nilai $\mathrm{K}_{\mathrm{SO} 2}$ pada rentang $4-30 \mu \mathrm{g} / \mathrm{m}^{3}$

b. Kecepatan angin pada rentang $0,68-1,56 \mathrm{~m} / \mathrm{s}$

c. Suhu udara pada rentang $27-29,5^{\circ} \mathrm{C}$

d. Kelembaban udara pada rentang $0,11-16 \%$

e. \% lahan RTH pada rentang $68-80 \%$

f. \% lahan jalan/lahan kosong pada rentang $16-22 \%$

g. $\%$ lahan bangunan pada rentang $5-11 \%$

h. \% lahan badan air pada rentang $0-7 \%$

Persamaan tersebut dapat dijadikan dasar simulasi berapa persen lahan RTH dan unsur ruang lain yang diperlukan untuk mendapatkan nilai reduksi $\mathrm{SO}_{2}\left(\mathrm{~K}_{\mathrm{SO}}\right)$ yang optimal dengan keadaan meteorologi yang ada. Persamaan tersebut dapat juga digunakan untuk evaluasi ketercukupan lahan RTH yang ada di Kota Surabaya, sebagai bahan pertimbangan untuk usaha perbaikan kualitas udara di Kota Surabaya.

\section{KESIMPULAN}

Berdasarkan penelitian yang telah dilakukan, beberapa kesimpulan yang dapat diambil yaitu pada hasil korelasi antara faktor meteorologi terhadap konsentrasi $\mathrm{SO}_{2}$ menunjukkan seluruh faktor meteorologi berkorelasi negatif atau berbanding terbalik terhadap konsentrasi $\mathrm{SO}_{2}$, selain itu faktor meteorologi juga terlihat berpengaruh signifikan terhadap konsentrasi $\mathrm{SO}_{2}$.

Sedangkan hasil korelasi antara unsur ruang terhadap $\mathrm{K}_{\mathrm{SO} 2}$, menunjukkan bahwa seluruh unsur ruang kecuali unsur jalan/lahan kosong memiliki korelasi negatif atau berbanding terbalik terhadap $\mathrm{K}_{\mathrm{SO}}$, dalam uji regresi terlihat pula bahwa faktor kelembaban udara memiliki pengaruh yang paling signifikan terhadap nilai reduksi $\mathrm{SO}_{2}$.

Hasil uji regresi juga menghasilkan sebuah persamaan linear berganda yang dapat digunakan untuk meningkatkan nilai reduksi $\mathrm{SO}_{2}$ serta memberikan hasil akurat $\left(\mathrm{R}^{2}>0,6\right)$ apabila diimplikasikan pada kondisi tertentu.

\section{UCAPAN TERIMA KASIH}

Penulis mengucapkan terimakasih kepada pengelola Taman Bibit 2 Wonorejo dan pihak Dinas Lingkungan Hidup Kota Surabaya, khususnya Bagian Lab DLH selaku fasilitator dan penyedia data yang digunakan pada penelitian ini. 


\section{DAFTAR PUSTAKA}

[1] S. Fardiaz, Polusi Air dan Udara. Yogyakarta: Kanisius, 2011.

[2] M. H. D. B. Istantinova and D. S. Handayani, "Pengaruh Kecepatan Angin, Kelembaban dan Suhu Udara Terhadap Konsentrasi Gas Pencemar Sulfur Dioksida (SO2) dalam Udara Ambien di Sekitar PT. Inti General Yaja Steel Semarang," Universitas Diponegoro, 2012.

[3] K. RI, "Kementrian Kesehatan RI," 2016. [Online]. Available: http://www.depkes.go.id/.

[4] WHO (World Health Organization), "Air Quality Guidelines for Europe Second edition,” WHO Reg. Publ., vol. 1, pp. 194-198, 2000.

[5] D. Prabhandhari, "Analisis Status Kualitas Udara Lima Kota Metropolitan di Indonesia," Institut Pertanian Bogor, 2014.

[6] J. E. M. Zhao. K. Zhao and J. Gao, "Impacts of Urban Forests on Offsetting Carbon Emissions from Industrial Energy Use in Hangzhou," J. Environ. Manage., vol. 9, pp. 807-813, 2009.

[7] I. B. Santoso dan S. Mangkoedihardjo, "Time Series of Carbon Dioxide Concentration in the Ambient Air to Determine Greenspace
Area," Int. J. Acad. Reasearch, vol. 6, pp. 224-229, 2012.

[8] Muzayanah, "Model RTH untuk Reduksi PM10 (Particulat Matter 10) Udara Ambien," Universitas Brawijaya, 2016.

[9] Winardi, "Analisis Dispersi Gas Sulfur Dioksida (SO2) Dari Sumber Transportasi Di Kota Pontianak," Universitas Tanjungpura Pontianak, 2015.

[10] S. Baja, Perencanaan Tata Guna Lahan dalam Pengembangan Wilayah (Pendekatan Spasial dan Aplikasinya). Makassar: Andi Offset, 2012.

[11] B. Tjasyono, Meteorologi Terapan. Bandung: ITB, 2008.

[12] B. Chandra, Pengantar Kesehatan Lingkungan Jakarta. Jakarta: Penerbit Buku Kedokteran, 2006.

[13] R. Pradana dan E. Heriyanto, Analisis Pemantauan Kualitas Udara pada Saat Arus Mudik dan Balik Lebaran di Gerbang Tol Cikampek Tahun 2009. Jakarta: Puslitbang BMKG, 2011.

[14] S. W. Syamdermawan and E. Kurniawan, "Pengaruh Ruang Terbuka Hijau Terhadap Kualitas Lingkungan Pada Perumahan Menengah Atas," Universitas Brawijaya, 2012. 